\title{
Benin on the Axis of the Law of the Primate City: The Case of Cotonou
}

\author{
Tek Büyük Kent Kuramı Ekseninde Benin: Cotonou Örneği
}

Bilge Kağan ŞAKACI

Doç. Dr., Eskişehir Osmangazi Üniversitesi, İ̈BF,

Siyaset Bilimi ve Kamu Yönetimi Bölümü, ksakaci@gmail.com

https://orcid.org/0000-0002-5230-508X

\author{
Abdel Bais SOUMANOU \\ Bilim Uzm., Bă̆ımsız Araştırmacı, abdelbaissoumanou@gmail.com \\ https://orcid.org/0000-0001-8577-4037
}

\section{Selçuk ÖZKAYA}

Arş. Gör., Eskişehir Osmangazi Ünversitesi, İBF,

Siyaset Bilimi ve Kamu Yönetimi Bölümü, mnselcukozkaya@gmail.com

https://orcid.org/0000-0002-0008-7543
Makale Başvuru Tarihi: 18.08.2021

Makale Kabul Tarihi: 18.12.2021

Makale Türü: Araştırma Makalesi
Keywords:

Primate City,

Urbanisation,

Benin,

Cotonou,

Anahtar Kelimeler:

Tek Büyük Kent,

Kentleşme,

Benin,

Cotonou,

\section{ABSTRACT}

Jefferson's "law of the primate city" states that the principal city of a country always disproportionately and deliberately represents the national economic capacity and the sense of nation in the population. This study examines the extent to which Cotonou, the economic capital of Benin, is fully in line with Jefferson's "law". Some spatial and situational factors were highlighted to show how Cotonou has become the most populous city and dominant economic city in Benin. Considering that Cotonou is disproportionately large and has a significant share of the country's economic capacity, it is clear that today there is some uncertainty as to whether Cotonou is truly representative of national feeling. In order to clarify this issue, an explanation of the cultural landscape, a literature review and interviews with Beninese residents are conducted to assess the extent to which Cotonou represents national feeling. Furthermore, it is noted that as Benin modernizes, Cotonou will continue to attract more people from other parts of Benin and may therefore become more representative of the country's cultural identity.

\section{ÖZET}

Jefferson'un "Tek Büyük Kent Kuramı”; bir ülkenin ana şehrinin daima nüfusta orantısız ve istinai şekilde ulusal ekonomik kapasiteyi ve ulus duygusunu temsil ettiğini ifade etmektedir. Bu çalışma Benin'in ekonomik başkenti olan Cotonou'nun, Jefferson'un "kuramına" tam olarak ne ölçüde uygun olduğunu incelemektedir. Alansal ve durumsal bazı faktörler; Cotonou'nun, nasıl Benin'in en yüksek nüfuslu ve ekonomik olarak dominant kenti olduğunu göstermek için vurgulanmıştır. Cotonou'nun, ülkenin ekonomik kapasitesinin önemli payına ve orantısı olarak geniş nüfusa sahip olması dikkate alındiğında, Cotonou'nun ulus duygusunu gerçekten temsil edip etmediğine ilişkin bazı belirsizlikler netleşecektir. Bu durumu netleştirmek adına, Cotonou'nun ulus duygusunu temsil edip etmediğini değerlendirmek için; kültürel peyzaj açıklamasında, literatür taramasında ve Benin sakinleriyle görüşmelerde bulunulmuştur. Bununla yanında, Benin modernleştikçe, Cotonou'nun ülkenin diğer yerlerinden insanları çekmeye devam edeceği ve ülkenin kültürel kimliğini daha çok temsil edebileceği belirtilmiştir. 


\section{INTRODUCTION}

Most countries in the world have a city that dominates in terms of population and acts as the political, economic and cultural centre of its realm. Geographers call such an entity a "primate city"; a concept that was first introduced by Mark Jefferson in 1939. Jefferson established a law of the primate city to explain the pattern of city size distribution in a country. According to the law, "the principal city of a country is always disproportionately large and exceptionally expressive of its national capacity and feeling" (Jefferson, 1939:232). In the mid-twentieth century, the primate city and the concept of city size distribution were examined with varying results in different countries and political and regional units (Berry, 1961; Reed, 1972).

As evidenced by numerous studies on almost every continent of the world, there has been a revival of interest in these concepts in recent years. In some parts of the world, the phenomenon of urban primacy is found to be much more observed. This is the case, for example, of London, Paris, Buenos Aires and Cairo, which are primate cities in their respective countries (Dzik, 2018:4). These cities not only represent capitals around which the political, economic and cultural life of their countries revolves, but they are also monuments of the nation's history. However, in other countries, the phenomenon of primacy is somewhat obscure. Several studies have shown that Cotonou is the main city (INSAE, 2013) and the economic capital of Benin. Given the multiple opportunities that this city offers, Cotonou is constantly welcoming new inhabitants. Thus, based on the literature on primate cities and the realities of Benin, questions may arise as to whether a disproportionate city is always still a true primate city in the context of Jefferson's law.

Since the creation of the first cities, urbanisation movements have continued and have progressively reached the whole world. Urbanisation has been one of the most significant developments in Third World countries since the second half of the 20th century. From the 1950s, the number of urban areas in West Africa increased from 152 to 2,000. In Benin, the urbanisation rate jumped from 10\% in 1960 to $36 \%$ in 1992. According to national studies of Benin's long-term prospects (PNUD, 2000), this rate could rise to 65\% in 2025 (Gnéle, 2010). In 2018, the urbanisation rate in Benin was already $47.31 \%$ (Atlasocio.com, 2021). Most of the urban population is concentrated in two cities: Cotonou and Porto-Novo. Cotonou is the economic capital and Porto-Novo the administrative and political capital. In 1961, 68\% of the urban population lived in the two cities; in 1979 and 1992, they still contained $51 \%$ and $40.5 \%$ of the country's urban population respectively. However, since the end of the 1950s, Cotonou has received more candidates for rural exodus than Porto-Novo. Through a cumulative process of acquiring new tasks supported by a polarisation of urban public investments, Cotonou rose to the top of the urban framework and ended up becoming the metropolis of Benin by appropriating the urban functions of economic, political and administrative command (Sébastien, 1999:90).

Unlike many nations where the relationship between administrative and economic capitals is expressed in terms of the demographic and economic supremacy of one or the other city, Cotonou arrogates the administrative and political command function traditionally assigned to the capital of a country, in addition to these characteristics (Sébastien, 1999:90). According to the National Institute of Statistics and Economic Analysis (INSAE) of Benin, the population of Benin was 10,008,749 in 2013. Cotonou was the largest city in Benin with a population of 679,012. Abomey-Calavi had 655,965 inhabitants. However, it should be noted that this high population of Abomey-Calavi was largely caused by Cotonou, since thirty years ago Abomey-Calavi was only a village. Given the proximity between these two cities and especially given the lack of space in Cotonou, migrants who came to Cotonou for opportunities were obliged to settle in Abomey-Calavi while carrying out their various activities in Cotonou. Abomey-Calavi, though administratively autonomous, had close relations with Cotonou. It hosted a large part of Cotonou's population. For this reason, Abomey-Calavi was seen as Cotonou's satellite city or often referred to as a dormitory town. Considering Abomey-Calavi as a satellite city of Cotonou, the urban area of Cotonou could still be estimated at more than 1,200,000 inhabitants. Porto-Novo, which in this case became the second largest city in Benin, had 264,320 inhabitants compared to 255,478 for Parakou, the third largest city in Benin (INSAE, 2013).

Yet, in his seminal work, Jefferson argues that the primate city attracts its inhabitants from all parts of the country and thus expresses the national disposition more fully than any other colonised region (Martin, 1961). This seems to be the case today for most primate cities (Reed, 1972; Crampton, 2005). It would seem that Cotonou may partly fit Jefferson's "national capacity" if it is based on economic dominance and the influx of migrants from all over Benin. Our hypothesis is that Cotonou carries properties of the Jefferson's law of primacy about national feeling, economic dominance and population. 


\section{PRIMATE CITY AND URBAN PRIMACY}

The concepts of primate city and urban primacy were first introduced by geographer Mark Jefferson in 1939. These two closely related concepts are rooted in theoretical approaches to urbanization in geography and in the sociology of human ecology that relate to "central places" and "urban systems" (Timberlake, 2019:1). As Jefferson pointed out, the concept of primacy had long been recognized by another name, a name widely used at the time of his writing (Meyer, 2019:131). "Outside of America", as Jefferson put it, "capital" means the same as "primate city" (Jefferson, 1939:227).

He thus noted in this regard that his "law of the primate city" could just as well have been called "The Law of Capitals". Jefferson therefore explained that in American usage the word "capital" simply referred to a seat of government, which may or may not be a dominant metropolis within its political unit. Indeed, for the sake of better understanding his general law that he had discovered and to avoid any sort of ambivalence, Jefferson had preferred to introduce a familiar name. He then replaces the word "capital" by "primate city". Since Jefferson recognized that the phenomenon he called the primacy was already recognized under other names, to better understand the good sense of the concept of primate city, it would be important to recall some clarifications on the concept of primacy given by the pre-Jefferson authors according to the different concepts or names used by them. For Thomlinson, Alexandre Le Maître (1682) in his work "La Métropolitée" pleaded in favour of a national centre whose geographical, political, economic, demographic and cultural predominance was ahead of "the primate city" of Jefferson (Thomlinson, 1976:566). To designate this centre in his work, Le Maitre used the terms "capital city" and "metropolitan city". At the beginning of the American Cloud, the term "capital" meant not only the centre in which the government resided but also defined itself as a single city dominating all its political unit. According to Jefferson, the term "capital" in other languages has two uses. One of them is the seat of government of a country and the other is a manner comparable to a "primate city" (Topalov et al., 2010).

In 1828, Noah Webster defined "capital city" as "the metropolis or chief city of an empire, kingdom, state, or province" (Webster, 1973[1828]:1). For the geographer William Darby, a simple seat of government which is not provided with all its functions could not be considered as a true "capital" (Darby, 1828:535-611). We dare to understand from Darby's assertion that a real capital is a real seat of government which is not only provided with all its attributes, but also which is dominant. At the beginning of the 20th century, a comprehensive dictionary of American English defined the "capital" as "[t]he city or town which is the official seat of government in a country, state, or province, or of justice in a county" (Whitney and Smith, 1911:804). Based on these different definitions of the term "capital" used by some pre-Jefferson authors to deal with the phenomenon of primacy, we can agree with Jefferson who thought that another term or concept was indeed necessary to convey its significance to readers in the United States and around the world.

Jefferson introduced the concept of primate city and urban primacy to show the pre-eminence of large cities in a country. The primate city is most often defined as the most populous city in a country, the largest in a territorially circumscribed group of cities. In other words, a primate city is a disproportionately large city in terms of population size compared to other cities contained within a given demarcated geographic area, such as a region or nation (Timberlake, 2019:1). It is a city to which ambitious people flock and natives can never imagine leaving (Lyman, 1992:24).

Jefferson (1939) defined urban primacy as the ratio of the population of the largest city to that of the second largest city or the second and third largest city. He also defined it as a city of great importance and a very high superiority over other cities of a nation (Short and Pinet-Peralta, 2009:1246). He used this notion to explain the phenomenon of large cities, which not only attract most of the population but also where the country's economic activity is concentrated. The primate cities are characterized by "the presence of the finest goods, the rarest items, the greatest talents, the most skilled workers of every science and art. Fame and fortune are found in these cities. They are always to be found there many young people in search of fame, opportunity and fortune" (Jefferson, 1939:226-227).

They are also the best markets for all exceptional products. In other words, factors such as the economic success and efficiency of a single large city, the ease of providing skilled labour and technical personnel and the lack of capital are the main factors that justify the formation of a primate city. The economic advantages and the benefits of collection in certain centres, ready infrastructure, services provided by banking and management institutions, large local markets and cheap labour, culture, education, health and entertainment services are among the main factors that develop a primate city. Despite the fact that many economic benefits can be obtained in countries where this rule is valid, many social problems are encountered, although there is an 
interregional imbalance (Keleş, 2020:139-140). In short, primate cities represent the high points of national life. Jefferson therefore argued that primate cities play an important generative role in national development. Referring to Jefferson's meaning, urban primacy has been viewed as a permanent condition that develops regardless of high displacement rates of population growth or the temporary blossoming of secondary urban centres (Reed, 1972:288).

The enunciation of "The Law of Primate Cities" was the product of many years of reflection by Jefferson. It all started when Jefferson noticed people, dwellings and culture, and realized that human beings have created patterns on the face of the earth. The idea of the concept of "primate city" was manifested in 1931 when Jefferson was writing an article entitled "The Distribution of Urbanization" whose main idea was the function of the super city. In this article, he presented the distribution and importance of major cities around the world (Jefferson, 1931:126). In 1936 Jefferson revised one of his older articles titled "Man in Europe". The objective of this revision was to explain the factors responsible for the population growth rate for each of the European states. Thus, the sizes of the cities and the causes of the population growth of the cities had greatly interested Jefferson; which had therefore led him to classify the cities of several countries in decreasing order of size to end up excelling with his notion of the primacy of the city. The Law of Primate Cities was introduced in front of the Association of American Geographers in Cambridge in December 1938 (Jefferson, 1939:226).

According to this law: "All over the world it is the Law of the Capitals that the largest city shall be super eminent, and not merely in size, but in national influence" (Jefferson 1939:227). Several reasons prompted Jefferson to declare his law. Based on the 46 most advanced countries and comparing the population size of the first city to that of the second city in those countries, Jefferson found the following: in 18 of the 46 countries selected, he notes that the first city was at least three times the size of the second city. In 28 cases, he finds that the first city was twice the size of the second, etc. (Jefferson, 1939:227).

His conclusion was that in many countries the largest city was two or three times the size of the neighbouring city, with a population ratio of around 100: 30: 20. The real exceptions to this law of Jefferson were the British dominions such as Spain, Italy and Russia. Indeed, after numerous analyses, it was found that this law elaborated by Jefferson takes into account three main factors that allow for the detection of the presence of a single large city (primate city) that is disproportionate in terms of size and influence compared to the other cities in a country.

The first important factor in the growth of a big city is its primacy among the big cities of the country, its accession to a much larger number of inhabitants. By thus dominating the country, its size and its activities become very important factors of seduction allowing to attract other inhabitants. As a result, the primate city becomes even larger and more disproportionate to the other cities in the country (Rosenberg, 2019). That's why Jefferson says: "But once a city is larger than any other in its country, this mere fact gives it an impetus to grow that cannot affect any other city, and it draws away from all of them in character as well as in size. It is the best market for all exceptional products. It becomes the primate city" (Jefferson, 1939:227).

The second important factor that enables a large city to outperform other large cities in a country is its national capacity. Speaking of national capacity, Jefferson was referring to the economic pre-eminence of primate cities in a country. In other words, these large cities are in fact the dominant economic centres or economic lungs of their countries. "All great cities have, as important factors in their growth, the productivity of their region and its extent, as well as their situation with regard to the chief lines of movement of internal and external commerce. Cities generously endowed with these two elements of growth are likely to be very great cities. New development of resources or acquisition of new productive areas, or new development of transportation lines that favour them more than other cities are likely to cause them a sudden increment of population" (Jefferson, 1939:78-79).

Thus, in these cities is practiced almost all the public or private affairs of a country; from trade to manufacturing and transport, which promotes rapid exchanges. And it is in this that primate cities are the centres of creation and accumulation of wealth. Because of becoming places which offer a better potential of resources, these cities continue to attract the population and become the centres of interest of their country. As for the third important factor, it concerns national sentiment. It should be noted that this concept of "national feeling" is ambiguous. Thus, in this present study, the meaning of "national feeling" is presented as the city being representative of the history and culture of a country. By assigning each country a cultural index that could indicate the degree of cultural achievement that country had achieved, Jefferson noticed that these indexes enjoyed good popularity. The results of his experiments had therefore shown that a country with a high cultural index had a large population (Jefferson, 1911:241-265). 
It should be noted that the cultural index is supposed to indicate the degree of cultural achievement that a country has attained using criteria such as schools, patents, cities, communications, railroad freight, foreign trade, mail delivered per capita, telegraph, telephone, automobiles and art galleries. Thus, Jefferson's "Law of Primate Cities" has been added a new dimension and becomes: "A country's leading city is always disproportionately large and exceptionally expressive of national capacity and feeling" (Jefferson 1939:231). In presenting his law, Jefferson showed that most of the inhabitants of the primate city are migrants. Indeed, every corner of the country brings some of its most energetic and active spirits to then contribute to the growth of the primate city. In thus contributing to its growth, the primate city "thus expresses the national disposition more fully than any other city" (Jefferson, 1939). This allows the various migrants not to completely lose the link with their province of origin. This is why Jefferson states that "the primate city contributes greatly to the unification of the country" (Jefferson, 1939). A unifying effect that the primate city does not share with the other provinces of the country. It then becomes the spirit and soul of the nation.

However, it should be noted that even after Jefferson introduced the concept of the primate city, some postJefferson writers criticized the concept. Other writers preferred to use other names for the phenomenon of primacy at the expense of Jefferson's concept. Cybriwsky criticized the concept of "primate city" used by Jefferson. It shows that in correct English, the adjective "primate" is not synonymous with "primary or first rank" but rather refers to a zoological classification (Cybriwsky, 1998:234). As for the Oxford English Dictionary, the meanings of the term "primate" in the sense of the natural sciences referred to "social rank" (Meyer, 2019:143).

There are also alternative usages of primate city. The economist Kenneth Boulding used the term "capital city" to denote "the largest city in the country", one that "dominates the life of the country, acting as a centralized focus for inputs of information and outputs of authority and, as the derivation of the word implies, as a 'head' to the body of the rest of the country" (Boulding, 1968:1114). Jane Jacobs in the 1960s, employed the concept "genuine capital" to refer to the dominant city of a country and which was also the seat of government (Jacobs, 1969:143). In her work which consisted of evaluating the reasons which could lead a country to have a significant city, a primate city, Jacobs used the concept of "elephant city" to designate this centre (Jacobs, 1969:172). This lack of familiarity of Jacobs with the concept of the primate city was also pointed out by Roger Clark. In one of her analyses, she explained that nations that depend on the export of manufactured goods breed "elephant cities" (Clark, 1988:42).

British historian Perry Anderson uses a German word "a true Hauptstadt" to refer to a city that is at the centre of a country's political, economic and cultural life. He also suggested some synonym such as "Metropole", "Zentrum", and "Residenz" (Anderson, 2009:226). In addition to these different authors cited above in the time after Jefferson, several Francophone and Anglophone social scientists have also used several designations to deal with the phenomenon of urban primacy while all these authors could well have continued to use the same term as Jefferson had introduced (Meyer, 2019:133).

Nevertheless, several post-Jefferson authors have used the concepts of the primate city and urban primacy introduced by Jefferson in their numerous explanations, although the opinions are often controversial. Standard dictionary of geographic concepts defines urban primacy as "the largest city's pre-eminence in economic, social, and political affairs" or as "a city's predominance within an area" (Johnston, 2009:580). According to Sawers, urban primacy is defined as "the overwhelming economic, social, demographic, and political dominance of the largest city" (Sawers, 1989:841). For Johnston, primacy is generally explained by "the small size of the country, the export orientation of its trade and a recent colonial past" (Johnston, 1994). Michael Pacione specifies that a primate city is "dominant not only by the size of its population, but also by its role as the political, economic and social centre of the country" (Pacione, 2005:673).

All these clarifications that we have just given above, allow us to affirm that the understanding of the concept of urban primacy or primate city depended on the historical process and various factors. The period before Jefferson explained the concept of urban primacy compared to a seat of government. For the authors of this period, the primate or dominant city of a country was very much relative to the place where the official seat of the government of that country was erected, even if it sometimes takes on another meaning. As for Jefferson, he explained a lot about the phenomenon of urban primacy in relation to the size of population. For him, the primate city is therefore the city that is disproportionate in terms of population. To detect this phenomenon, he has always compared the population size of the main city of a country with the population size of the second and in some cases the third city of that country. As a result, for the period after Jefferson until today, the concept of urban primacy is explained in terms of certain factors. Factors that take into account economic, historical, political, demographic, cultural and geographical aspects. 


\section{BENIN AND COTONOU}

\subsection{Benin}

Originally, the land of present-day Benin was occupied by several kingdoms. The most prominent were called Danhomé (Abomey), Xogbonou (Porto-Novo), Allada, Nikki, Kouandé, Kandi. The first rulers of Abomey and Porto-Novo came from the Adja-Fon migration from neighbouring Togo (Tado). The other peoples came from present-day Nigeria, Niger or Burkina Faso. Thus, the country was once a home to ancient and brilliant civilisations, built around these kingdoms: city-States. These well-structured political entities had functional urban centres. They had developed a local trade, based from the 17th century on the slave trade, then on the oil palm trade after the abolition of the slave trade in 1807. This trade economy favoured the installation, along the coast (nicknamed the "Slave Coast"), of trading posts controlled by the English, the Danes, the Portuguese and some French. In 1704, France was authorised to build a port at Ouidah, while in 1752, the Portuguese discovered Porto-Novo. In 1863, the first French protectorate was established with King Toffa of Porto-Novo, who sought help against the claims of the King of Abomey and attacks from the British established in Lagos. In the same year, Glèlè, King of Abomey, authorised the French to settle in Cotonou. In 1882, the sovereign of the kingdom of Porto-Novo signed a new protectorate agreement with France, which sent a "French resident" to assist the king. In 1894, the French, defeating the local kings, created the colony of Dahomey and its dependencies. The territory took the name of the most preponderant and most resistant kingdom to foreign occupation: Danhomé with its legendary king Béhanzin (Présidence de la République du Bénin, 2021).

Colonial period: When the Chief of Porto-Novo, a man who was personally linked to King Glèlè of Dahomey signed a friendship and commercial treaty with France in 1851, the British captured the city of Lagos in 1861. Thanks to treaties signed in 1868 and 1878, France came into possession of the Cotonou region located between Ouidah and Porto-Novo. In order to avoid and protect themselves from the traps of the king of Dahomey who had expansionist aims, a protectorate treaty was signed in 1883 between the king of Porto-Novo and France. Gbêhanzin, son of King Glèlè who succeeded his father tried to take back the region occupied by France, but the latter was betrayed in 1892. He was thus deported by the French authorities on March 30, 1894. This encouraged the establishment of French settlements in southern Dahomey. Following the failure of Gbêhanzin, the northern Bariba kingdom opposed fierce resistance to French colonization. In fact, in the 1899s, Dahomey was integrated into French West Africa (AOF). During an assembly in Nigeria, the French authorities in agreement with Great Britain fix the borders of Dahomey and Germany wins Togo. During the interwar period, a high level of education was observed, especially in southern Dahomey, thanks to religious missions. This therefore made it possible to designate Dahomey as one of the main political and intellectual centres of the AOF. From this time, several political parties were created and at the same time an opposition against the colonial system was developing. By fighting alongside France during World War II, Dahomey not only became a French overseas territory in 1946 but also an autonomous state within the French Community on December 4, 1958. Protectorate in 1884, then French colony of Dahomey, Benin achieved full independence on August 1, 1960, under the name Republic of Dahomey and entered the United Nations the following month. It was not until 1975 that the country adopted the name of Benin (Présidence de la République du Bénin, 2021).

After independence: Benin has had a turbulent political history since it gained independence. The first twelve years were marked by political and economic instability. It was subject to five military putsches, four constitutions and nine heads of state and government. These movements stopped only in 1972 following the military coup of General Mathieu Kérékou and the acceptance of the Marxist-Leninist ideology in 1974. A transitional government, established in 1990, paved the way for the return of democracy and a multi-party system. Following the presidential election of March 1991, Nicéphore Soglo replaced Mathieu Kérékou as President of the Republic. Mathieu Kérékou was elected in his turn in March 1996 then re-elected in March 2001. In March 2006, Dr Yayi Boni, former Director of BOAD, was elected President of Benin and re-elected in 2011. Following the presidential elections of March 20, 2016, Mr Patrice Guillaume Athanase Talon was elected President of the Republic and has been leading the country since April 6, 2016 (Présidence de la République du Bénin, 2021). 


\subsection{National Urban Context and Development of Beninese Cities}

The national urban context is linked to the configuration of Beninese cities and the national framework. Based on the different criteria for defining cities in Benin, there are about 100 cities and urban centres. These cities are thus grouped according to three criteria: age, size of the administrative level, demographic and economic weight (Danvidé, 2015:67). According to this grouping, there are three groups of cities in Benin.

- The old pre-colonial cities: Abomey, Porto-Novo, Nikki, Djougou, Kandi, Ouidah, Athiémé; which have lost not only their influence but also their demographic is slower growth.

- Colonially created cities: Cotonou, Bohicon, Parakou, Azové, Aplahoué; whose demographic and economic weight explains their high power of attraction.

- Cities born of the State's desire to create political-administrative axes whose creation does not have too much influence on the urban system for example Natitingou, Lokossa.

Indeed, a new definition of a city has been introduced. A city is thus considered as "any agglomeration of 10,000 inhabitants or more and possessing at least four of the following infrastructures: post and telecommunications, revenue collection, public treasury, bank agency, water supply, electricity, health centre and high school" (INSAE, 1976 cited by Danvidé, 2015:67).

This definition adopted in 1992 considers an administrative criterion based on communal status and a population of at least 10,000 inhabitants. In 2002, a new functional criterion relating to activities was added to the definition and defined urban. The fourth general population and housing census (RGPH) conducted in 2013 counted 9,983,884 urban inhabitants (INSAE, 2013), compared to 6,769,914 in 2002 according to the third census (Danvidé, 2015:68). According to some sources, Benin currently has 12,500,000 inhabitants in 2021 (www.populationdata.net, 2021).

Table 1. Evolution of the population of the main cities of Benin from 1979 to 2013.

\begin{tabular}{|c|c|c|c|c|c|c|c|}
\hline \multirow{2}{*}{} & \multicolumn{2}{|c|}{ Populations 1979 } & \multicolumn{2}{c|}{ Populations 1992 } & \multicolumn{2}{c|}{ Populations 2002 } & Populations 2013 \\
\cline { 2 - 8 } & Total & Tx1979-1992 & Total & Tx1992-2002 & Total & Tx2002-2013 & \\
\hline Benin & 3.331 .210 & $2.82 \%$ & 4.915 .555 & $3.25 \%$ & 6.769 .914 & $3.51 \%$ & 9.983 .884 \\
\hline Cotonou & 320.348 & $3.76 \%$ & 536.827 & $2.17 \%$ & 665.100 & $0.18 \%$ & 678.874 \\
\hline Porto- Novo & 133.168 & $2.14 \%$ & 179.138 & $2.24 \%$ & 223.552 & $1.48 \%$ & 263.616 \\
\hline Parakou & 60.915 & $3.86 \%$ & 103.577 & $3.76 \%$ & 149.819 & $4.81 \%$ & 254.254 \\
\hline
\end{tabular}

Source: Data taken from INSAE statistics, 2013

\subsection{Cotonou}

Initially, the city of Cotonou was a very richly vegetated and densely forested area (N'bessa, 1979). The city was created during the reign of King Ghézo (1818-1858) by representatives of the King of Abomey who resided in the area. With its real name OKOUTONOU, which means "on the edge of the lagoon of death" (Sébastien, 1999:91), present-day Cotonou is a colonial city that developed at the end of the 19th century. In 1888, the area of the city of Cotonou was ceded to the French by the king of Abomey, which had the effect of accelerating the process of its development (Danvidé, 2015:70).

Being the main economic city of Benin and the capital of the Atlantic and Littoral departments, Cotonou is located on the coastal strip of Benin, on a narrow strip of land bounded to the south by the Atlantic Ocean, to the north by Lake Nokoué, the west by the municipality of Abomey-Calavi and to the east by the municipality of Sèmè Kpodji (Danvidé, 2015:70). The city of Cotonou covers $79 \mathrm{~km}^{2}$ and is cut in two by a natural channel of more than $4 \mathrm{~km}$ allowing lake waters coming together with the sea. The two parts of the city are connected by three bridges: the Old Bridge, the Martin Luther King Bridge and the Eisenhower Bridge (Danvidé, 2015:70).

Administratively, the city of Cotonou is subdivided into thirteen districts and one hundred and forty (140) neighbourhoods. A special-status commune and essentially urban, Cotonou is the only city in the country to be set up as a department: that of the Littoral. It is governed by a municipal council headed by a mayor (Gnélé, 2010:76). 


\subsubsection{Population and Demographic Evolution in Cotonou}

The expansion of the city of Cotonou has started since the end of the Second World War. In the thirties, the city of Cotonou was only a small town next to the large Porto-Novo. For example, in 1932, Cotonou had only 5,000 inhabitants, while Porto-Novo already had 20,000 (Gnélé, 2010:88). In 1945, Cotonou was the second city after Porto-Novo with a strong population of 18,000 inhabitants (Sébastien, 1999:91). This rapid development of the city of Cotonou was not only linked to the development of economic activities and administrative services but also to the construction of the "wharf" (Gnélé, 2010:88).

The city of Cotonou had 320,332 inhabitants in 1979 then to 536,827 inhabitants in 1992. In 2002, the population of the city of Cotonou rose to 665,100 inhabitants. We can therefore note that the city of Cotonou experienced an increase of $7.7 \%$ between the years 1961 and 1979. A rate which decreased to $5.4 \%$ between 1979 and 1992 and $2.17 \%$ between 1992 and 2002. This decrease is due to the installation of a few inhabitants in the peripheral municipalities such as Abomey-Calavi and Sèmé Kpodji. In the 2010s, the population of the city of Cotonou was around 1,200,000 inhabitants (Gnélé, 2010:88). But given the observation of the demographic slowdown and the growth rate of around 2\%, the population of Cotonou was 679,012 inhabitants in 2013 (INSAE, 2013).

This increase which could allow the growth of the peripheral districts of the neighbouring cities such as Abomey-Calavi, Sèmè-Kpodji and Ouidah. According to some sources, Cotonou's urban area is 2.2 million inhabitants today (Bénin-tourisme, 2017). The only city to be established as a department, Cotonou appears to be the most important agglomeration of Benin with a population comparable to those of the most populous departments of the country such as the Atlantic, Ouémé and Borgou (Gnélé, 2010:88). With a demographic weight of around $10 \%$ of the national workforce, the population of the city of Cotonou is, in a way, the "reflection" of the national population (Gnélé, 2010:91-92).

According to INSAE, the population of Cotonou is characterized by a socio-cultural plurality in that most of the country's socio-cultural groups are represented. Among these nationalities, Fon and related $(56.7 \%)$ are in the majority, followed the Adja and related (18.3\%). Next come the Yoruba and related 11.5\%. The rest are made up of many minorities including the Dendi, Bariba, Haoussa, Peulh, Bètamari (INSAE, 2002). In the city of Cotonou, there are also several foreign nationalities, the majority of which are Lebanese-Syrians, IndoPakistanis, Togolese, Congolese, Nigerians, Nigerians (Ibo and Yoruba), Ivoirians and Sierra Leoneans. On the religious level, we distinguish Catholics, Muslims and other Christians (celestial and traditional cults).

\subsubsection{Economic Activities in Cotonou}

The country's leading economic city, Cotonou is a double gateway to Benin: a maritime entry through the port of Cotonou, and an entry to Nigeria (which became the leading economic power on the African continent in 2014) via the land border of Sèmè-Kpodji (Danvidé, 2015:100). Beninese metropolis, Cotonou is a gateway for doing business with other West African countries and particularly the UEMOA countries (Chabi, 2013). Like Benin, the city of Cotonou is also characterised by three sectors.

In Cotonou, the primary sector includes market gardening, floriculture, fishing (continental and maritime) and livestock. Market gardening is the most common form of urban agriculture and supplies the urban population with basic foodstuffs. The main cultivated products are Solanum, amaranth, carrot, cabbage, cucumber, leek, celery, tomato, beet, lettuce, radish, green bean, parsley, onion, chilli, horsehair and okra. As for floriculture, it concerns the cultivation of ornamental plants practiced along the main arteries and close to residential areas inhabited by senior officials and especially expatriates (Gnélé, 2010:103). Fishing is practiced in several ways in Cotonou. Industrial maritime fishing, artisanal maritime fishing is practised by some 952 fishermen, of whom only 412 are Beninese (43.28\%) and continental fishing practised mainly in Lake Nokoué. In the area of livestock, Benin has several species of domestic animals, including cattle, sheep, goats, pigs, numerous rabbits and grasshoppers and a variety of poultry (chickens, ducks, pigeons and other birds) (Gnélé, 2010:103).

The secondary sector in the city of Cotonou is relatively small but highly concentrated on the agro-food industry (SERHAU-SA / DPDM / MCOT, 2006). Apart from the predominant food industry, the other activities of the secondary sector in Cotonou encompass wood, rubber and plastics processing, printing, chemical industry, buildings and public works. This sector also includes artisanal activities of welding, ironwork, sculpture, basketry (Gnélé, 2010:104). 
Finally, the tertiary sector represents the most dynamic sector of the Cotonou economy. This sector employs only $36 \%$ of the working population and contributes the most to the formation of the local GDP. The success of this sector is linked to the geostrategic position of Benin, which makes Benin a transit corridor for imports from neighbouring countries or other countries in the region from the port of Cotonou (Gnélé, 2010:105). The Autonomous Port of Cotonou is the real lifeblood of the national economy, with $90 \%$ exchanges with abroad and more than $60 \%$ of the country's GDP, it is one of the largest ports in the region. It trades with Europe, North and South America and Asia, making Cotonou a "warehouse city" generating intense trade, handling and logistics (Benin-Tourisme, 2017). The tertiary sector in Cotonou encompasses not only trade but also considers banking and other services such as catering, tourism, transport and telecommunications.

\section{COTONOU CITY AND THE LAW OF THE PRIMATE CITY}

As said before, The Law of The Primate City consists of three criteria. One of these is that primate city is twice or three times higher than second biggest city in the country on the context of population. Second of these criteria is national capacity, that is, primate city is more developed than other cities in the country. Final of these criteria is national feeling. In this section, the extent to which Cotonou complies with The Law of The Primate City will be discussed. Primarily all of the criteria briefly will be examined and then third of the criteria will be processed through field research.

In 2013, according to the 4th census in the Republic of Benin by INSAE, the total population of Benin was $10,008,749$ inhabitants. But according to some sources, Benin currently has 12,500,000 inhabitants in 2021 (www.populationdata.net, 2021). It was found that Cotonou was the largest city in Benin with a population of 679,012. Its association with the city of Abomey-Calavi, which was its satellite city, increased its population to over 1,200,000 inhabitants. Porto-Novo was the second largest city in Benin with a population of 264,320 followed by Parakou which was the third largest city with a population of 255,478 (INSAE, 2013).

On the basis of this information from INSAE, and when the population of Abomey-Calavi (a satellite city of Cotonou) is combined with the population of Cotonou, it is easy to confirm that Cotonou fulfils the first element of Jefferson's law because it is disproportionately large. Also, it is important to remember that the city of Cotonou concentrates more than $45 \%$ of the assets of the ten (10) main cities of Benin. It is followed by PortoNovo (14.5\%) and Parakou (7.2\%) (Gnélé, 2010:101).

This means that Cotonou is appropriate to national capacity criteria. The "national feeling" in this study revolves around two aspects: the history and culture of a country. In other words, a city that reflects the history and culture of a country is then representative of the national feeling. Thus, the places below present various aspects of the cultural landscape of Cotonou. These places illustrate the juxtaposition of the modern Beninese metropolis and the country's recent history, combined with monuments to Benin's heritage. Events around the city of Cotonou reflect modern developments, some effects of globalisation and multicultural heritage. The cultural landscape of the city conveys conflicting messages about the extent to which Cotonou embodies national feeling. Related monuments can be sorted like;

1. Place of Red Star and Monument in Cotonou, Square and monument of the revolution in Cotonou

2. Memorial Square (former place of the Martyrs) in Cotonou

3. CICA Toyota roundabout from Vedoko in Cotonou

4. Republic, Reconciliation and Peace Square

5. Old building where King Béhanzin stayed

6. Cotonou prefecture building with Afro-Brazilian architecture style

7. Zangbeto Kpakliyaou World Headquarters: Toïgbé Convent of Cotonou

8. Dantokpa Market 


\subsection{Field Research}

The aim of this study is to examine the city of Cotonou in the context of Jefferson's original opinion. For this study, the qualitative method was adopted. This method allowed us to collect primary and secondary data. First, a theoretical framework was established by analysing what had been written about primate cities. Secondly, an extensive literature review on the geographical environment, history and culture of Benin and especially of the city of Cotonou was carried out in order to show on the one hand how the city of Cotonou has developed in contrast to other cities in Benin, and on the other hand, to determine whether or not Cotonou is considered to represent the culture of Benin today. In order to acquire broad knowledge, to organise field research and especially to integrate theory and literature review on the geographical environment, history and culture of Benin and the city of Cotonou, a correspondence with a small number of inhabitants of several towns and villages in Benin was conducted. Indeed, given the current health situation related to COVID-19 and the fact that this study is being conducted outside Benin, for the collection of some primary data, semi-structured online interviews (twenty-six inhabitants of different cities in Benin, generally lasting from fifteen to twenty minutes) were organised so that respondents could give their perceptions of Cotonou's geography, history and cultural attitudes. In some cases, these Beninese inhabitants were interviewed by email and in other cases, the interviews were conducted via social networks (WhatsApp, Facebook). Thus, three approaches were used not only to deepen the question of whether Cotonou reflects Beninese culture but also to assess whether Cotonou actually represents the historical, economic and political centres of Benin. The first method consisted of "reading" the cultural landscape by analysing the cultural indices and landmarks of the city of Cotonou. Secondly, several theses and scientific articles dealing with the cultural aspects of the city of Cotonou today were consulted. Thirdly, the results of the twenty-six online interviews were analysed using NVivo software. This is how it began of the formulation of a descriptive analysis of the Cotonou city's condition of primacy.

Various obstacles were encountered in the conduct of this study. Without affecting the validity of the results, this study suffers from three main limitations. Firstly, it should be mentioned that this type of study we are carrying out is usually carried out in countries where industrial capitalism has developed. Urban phenomena and urbanisation in the former socialist bloc and Third World countries have been the subject of scientific publications for a very short time. It should be noted, however, that this is mainly descriptive work rather than theoretical and analytical work. This explains the great lack of literature on this study in Third World countries and particularly in Benin. This situation has made it difficult for us to carry out our various analyses. The second limitation of this study concerns the current health situation related to COVID-19 and the fact that this study is conducted outside Benin. This could explain the small size of our sample. For the collection of some primary data, semi-structured online interviews were conducted so that respondents could give their perceptions of the geography, history and cultural attitudes of Cotonou. Unfortunately, most of the respondents did not keep their promise due to some difficulties encountered in Benin. Some respondents were faced with the problem of lack of computers and smartphones. Those who did have these tools were confronted with internet problems. The third limitation relates to the available demographic data. It was noted that the official or updated demographic data was from 2013. The recent data that did exist was unofficial and remained just estimates. This situation also prevented us from making rigorous analyses over time.

In order to achieve the research objectives, this study is structured in three chapters. The first chapter is devoted to the theoretical and conceptual framework and the literature review on primate cities. The second chapter briefly describes Benin and presents the city of Cotonou. The third chapter presents the different analyses. At this level, the current role of Cotonou in Benin's national capacity and sentiment has been addressed through some interviews with some Beninese residents in order to determine to what extent Cotonou could be the primate city of Benin. Furthermore, it should be noted that the condition of primacy in this study revolves around three elements: an excessively large population compared to other cities in the country; economic predominance and the symbol of national cultural identity.

In order to deepen our analyses, interviews were conducted with twenty-six Beninese residents, twenty of whom were men and six women. These interviews with these Beninese residents allow us to explain how the city of Cotonou has developed in relation to other cities in Benin and to better understand the issue of "national feeling". 
Table 2. Classification of the characteristics of the interviewees

\begin{tabular}{|c|c|c|c|c|}
\hline & 1. Sex & 2. Age & 3. Function & 4. City or region \\
\hline A & Male & 64 & Pensioner & Djougou (North Benin) \\
\hline B & Male & 63 & Pensioner & Kandi (North Benin) \\
\hline $\mathrm{C}$ & Female & 35 & Housewife & Parakou (North Benin) \\
\hline $\mathrm{D}$ & Male & 45 & Service worker & Porto-Novo (South Benin) \\
\hline $\mathrm{E}$ & Male & 23 & Student & Abomey-calavi (South Benin) \\
\hline $\mathrm{F}$ & Male & 37 & Service worker & Allada (South Benin) \\
\hline G & Male & 27 & Student & Abomey (South Benin) \\
\hline $\mathrm{H}$ & Male & 62 & Municipal councillor & Abomey-calavi (South Benin) \\
\hline I & Male & 33 & Student & Savalou (Centre Benin) \\
\hline $\mathrm{J}$ & Female & 27 & Student & Tchaourou (Centre Benin) \\
\hline K & Male & 31 & Service worker & Bantè (Centre Benin) \\
\hline $\mathrm{L}$ & Male & 29 & Student & Ouaké (North Benin) \\
\hline M & Male & 26 & Student & Pobè (South Benin) \\
\hline $\mathrm{N}$ & Male & 65 & Pensioner & Cotonou (South Benin) \\
\hline $\mathrm{O}$ & Male & 38 & Service worker & Naguélé (North Benin) \\
\hline $\mathrm{P}$ & Female & 42 & Housewife & Cotonou (South Benin) \\
\hline Q & Male & 38 & Service worker & Parakou (North Benin) \\
\hline $\mathrm{R}$ & Male & 23 & Student & Djougou (North Benin) \\
\hline$S$ & Female & 28 & Student & Kandi (North Benin) \\
\hline $\mathrm{T}$ & Male & 24 & Student & Dogbo (South Benin) \\
\hline $\mathrm{U}$ & Male & 60 & Pensioner & Abomey-calavi (South Benin) \\
\hline $\mathrm{V}$ & Female & 35 & Service worker & Cotonou (South Benin) \\
\hline W & Male & 60 & Service worker & Ouaké (North Benin) \\
\hline $\mathrm{X}$ & Male & 44 & University Professor & Agonlin (South Benin) \\
\hline $\mathrm{Y}$ & Male & 28 & Student & Bantè (Centre Benin) \\
\hline $\mathrm{Z}$ & Female & 27 & Housewife & Kandi (North Benin) \\
\hline
\end{tabular}

The field research was conducted by asking two main questions.

1. Does Cotonou represent the culture and image of Benin?

2. What are the advantages and disadvantages of having one big city like Cotonou?

Firstly, we tried to understand through our respondents, if Cotonou is the real Benin. To get there we asked the following question: Does Cotonou represent the culture and image of Benin? Eight (30.77\%) of those questioned answered with a "No" and five (19.23\%) thought that Cotonou represents the culture and image of Benin. What was surprising was that thirteen $(50 \%)$ of the respondents answered with both a "Yes" and a "No". For these thirteen people, Cotonou represents the image of Benin but does not represent the true culture of Benin. Thus, we asked these respondents to clarify their positions and a sample of responses is provided in the table above. Secondly, we asked respondents to give their opinion on the fact that Benin has a single large city like Cotonou that plays the functions of economic, political and administrative command of the country. While interviewee " $T$ " thought that there were only advantages to this fact and interviewee " $R$ " saw only disadvantages, twenty-four people thought that there were both advantages and disadvantages to having Cotonou as the only large city in Benin. For these interviewees, the development and modernisation of Cotonou gives a good image of Benin and allows other citizens from other countries to visit and do business in Benin. This allows the development of the country. But on the other hand, these people think that having Cotonou as 
the only large developed city is detrimental to other cities in Benin because regional disparities and inequalities may arise. This can also create development imbalances between cities and can sometimes lead to social unrest. Moreover, for these people, the modernisation of the city of Cotonou tends to make Benin's traditional values disappear.

\section{CONCLUSION}

Through this study, we have tried to demonstrate to what extent Cotonou, the economic capital of Benin, is in line with Jefferson's Law. Long before the advent of Jefferson's law on the primate city, it should be noted that the phenomenon of primacy had been discussed by some European and American authors from the end of the 17th century. These pre-Jefferson authors often used the name "Capital" or similar names in other languages to discuss this phenomenon. Yet, in daily American usage, the name "Capital" was understood as the seat of government, which in some cases could be the dominant centre within its fiefdom. In order to avoid ambiguity, Jefferson introduced a new concept followed by a law in 1939: "The Law of Primate City". According to this law, the principal city of a country is always disproportionate in population and exceptionally representative of the national capacity and feeling. It is understood from Jefferson's law that the phenomenon of urban primacy occurs when a single city in a country combines the following three fundamental aspects: a population that is too large in relation to the other cities in the country, economic predominance and the symbol of national cultural identity. Several post-Jefferson authors have criticized Jefferson's position. In addition to admitting that Jefferson's investigations had only taken into account the sovereign states existing in 1939 to explain the phenomenon of urban primacy, today many colonies in Africa and Asia display a high degree of primacy. PostJefferson authors believe that the explanation of the phenomenon of urban primacy could not be limited to these three elements proposed by Jefferson. However, several studies show that today the explanation of the phenomenon of urban primacy should take into account the political, economic, cultural, historical and demographic dimensions of the primate city. A second discussion related to the study of urban primacy concerns the role of primate cities as "parasitic" and "generative" instruments in the economies of developing countries. Like Jefferson, some post-Jefferson authors argue that economic growth in a country is often facilitated through primate cities. The presence of primate cities in a country allows for huge economies of scale. However, other authors argue that primate cities rarely serve as effective stimuli for economic growth. Instead, these large cities represent national parasites that absorb large resources from other parts of the country. These cities are sometimes seen as instruments that slow down the development of many countries. It should be remembered that this type of study that we carry out is usually conducted in developed countries. But in recent years, the authors have shown great interest in this study in Third World countries. Thus, we found that this study was appropriate for African countries, which today have a very high degree of urban primacy. It is in this perspective that we have chosen to study the case of Benin despite all the difficulties encountered during the realisation of this work.

Furthermore, what interested us most in this study was to show whether Cotonou fulfilled the three criteria of primacy pre-set by Jefferson. Numerous researches and statistics have shown that Cotonou was disproportionately large in terms of population (INSAE, 2013) and became the metropolis of Benin by appropriating the functions of economic, political and administrative leadership (Sébastien, 1999:90). Thus, it would be easy to point to Cotonou as the primate city of Benin when referring to its population size and economic predominance. It should be recalled that these two factors (population size and economic predominance) are all related to its site and situational privileges. However, the main concern is whether Cotonou meets Jefferson's third criterion. In other words, does Cotonou meet Jefferson's argument about national sentiment? The answer to this question will depend on an explanation or interpretation. Situational changes attracted people from other cities in Benin to Cotonou, creating a kind of Beninese fusion in the city from which a multitude of traditions and cultures could be observed in Cotonou. Although interviews with residents of regions outside Cotonou leave mixed or somewhat unfavourable opinions on whether this fusion created within Cotonou leads the city to express a national feeling, there does not seem to be too much external contempt for Cotonou. This is often not the case for primate cities in other countries. Thus, two facts caught our attention. As Benin continues to modernise, Cotonou will certainly attract more migrants from other parts of Benin. This may in time allow it to become more fully representative of Benin's modern national sentiment, bringing together all the factors of Jefferson's "Law of primate city". The second fact that represents a new avenue for further study is whether the situation of Cotonou (Benin's primate city) is comparable to other large cities in other West African countries that also have a primate city distribution in terms of population. 


\section{REFERENCES}

ANDERSON, Perry (2009), The New Old World, Verso Press, London.

ATLASOCIO.COM (2021), "Sources et Définitions", Atlasocia.Com Corporate Web Page, https://atlasocio.com/sources-et-definitions.php (Erişim Tarihi: 02.08.2021).

BÉNIN-TOURISME (2017), "Bienvenue au Bénin”, Benin Tourisme.Com Corporate Web Page, https://benin-tourisme.com (Erişim Tarihi: 02.08.2021).

BERRY, Brain J. L. (1961), “City Size Distributions and Economic Development”, Economic Development and Cultural Change, S.9(4), ss.573-588.

BOULDING, Kenneth E. (1968), “The City as an Element in the International System”, Daedalus, S.97(4), ss.1111-1123.

CHABI, Moïse (2013), "Métroploisation et Dynamiques Périurbaines: Cas de l'espace Urbain de Cotonou", Yayımlanmamış Doktora Tezi, Thèse de Doctorat en Géographie Humaine, Économie et Régionale, Université Paris Ouest Nanterre la Défense.

CLARK, Richard D. (1988), "The Primate and the Elephant City: A Tale of Two Theses", Social Science Quarterly, S.69(1), ss.40-52.

CRAMPTON, Graham (2005), "The Rank-Size Rule in Europe: Testing Zipf's Law Using European Data", ERSA2005 Conference, Amsterdam.

CYBRIWSKY, Roman A. (1998), Tokyo: The Shogun's City at the Twenty-First Century, John Wiley and Sons Publisher, Chichester.

DANVIDÉ, Taméon Benoît (2015), Gouvernance des Politiques de Planification Urbaine et Gestion des Inondations à Cotonou (Bénin), Yayımlanmamış Doktora Tezi, Thèse Unique de Doctorat pour l'obtention du grade de Docteur en: Urbanisme et Gestion de l'environnement (Université d'AbomeyCalavi) Géographie Humaine et Régionale (Université Paris 8).

DARBY, William (1828), View of the United States: Historical, Geographical, and Statistical, H. S. Tanner Publisher, Philadelphia (US).

DZIK, Anthony J. (2018), "Nuuk, Greenland: Site, Situation, and 'The Law of the Primate City", The Northern Review 48, Published by Yukon College, Whitehorse - Canada, ss.3-32.

GNÉLÉ, Jose Edward (2010), "Dynamique de la Planification Urbaine et Perspective de Développement Durable à Cotonou (Bénin)", Yayımlanmamış Doktora Tezi, Thèse de doctorat en Géographie et Environnement, Université d'Abomey-Calavi, FLASH.

INSAE (2002), Analyse des résultats du RGPH 3 (Tome 1) : Répartition spatiale, structure par sexe et âge et migration de la population au Bénin, Cotonou, Bénin.

INSAE, (2013), Enquête Démographique et de Santé (EDSB-IV) 2011-2012: Ministère du Développement, de l'Analyse Economique et de la Prospective, ICF International Calverton Publisher, Maryland (US).

JACOBS, Jane (1969), The Economy of Cities, Random House Publisher, New York (US).

JEFFERSON, Mark (1939), "The Law of the Primate City", Geographical Review, S.29(April), ss.226-232.

JOHNSTON, Ron (1994), "Primate City: Law of The", The Dictionary of Human Geography (Ed. Ron Johnston, Derek Gregory, Peter Hagget, David M. Smith, D. R. Stoddart), Blackwell Press, Oxford (UK), $3^{\text {rd }}$ Edition, ss.473.

JOHNSTON, Ron (2009), "Primate City: The Law of", The Dictionary of Human Geography (Ed. Derek Gregory, Ron Johnston, Geraldine Pratt, Michael J. Watts, Sarah Whatmore), Wiley-Blackwell Publisher, Chichester, $5^{\text {th }}$ Edition, ss.580.

KELEŞ, Ruşen (2020), Kentleşme Politikası, İmge Kitabevi, Ankara.

LE MAÎTRE, Alexandre L. (1682), La Métropolitée: de l'établissement des Villes Capitales, de Leur Utilité Passive et Active, de l'union de Leurs Parties et de Leur Anatomie, de Leur Commerce, \&c., Baltes Bockhout pour Jean Van Gorp Publisher, Amsterdam. 
LYMAN, Brad (1992), "Colonial Governance in the Development of Urban Primacy", Studies in Comparative International Development, S.27(2), ss.24-38.

MARTIN, Geoffrey J. (1961), "The Law of the Primate City Re-examined", Journal of Geography, S.60(4), ss.165-172.

MEYER, William B. (2019), "Urban Primacy before Mark Jefferson”, Geographical Review, S.109(1), ss.131-145.

N'BESSA, Benoît (1979), "Les Fonctions Urbaines de Cotonou”, Yayımlanmamış Doktora Tezi, Thése de Doctorat de 3éme cycle, Université de Bordeaux III.

PACIONE, Michael (2005), Urban Geography: A Global Perspective, Routledge Press, London (UK), $2^{\text {nd }}$ Edition.

PNUD (2000), Etudes Nationales de Perspectives à Long Terme (Bénin 2025): Alafia, PRCIG/NLTPS/BEN, Cotonou - Bénin.

POPULATIONDATA.NET (2021), "Afrique", Populationdata.Net Corporate Web Page, https://www.populationdata.net/continents/afrique/ (Erişim Tarihi: 02.08.2021).

PRÉSIDENCE DE LA RÉPUBLIQUE DU BÉNIN (2021), “La Géographie du Bénin”, https://presidence.bj/home/le-benin/geographie/ (Erişim Tarihi: 02.08.2021).

REED, Robert R. (1972), "The Primate City in Southeast Asia: Conceptual Definitions and Colonial Origins", Asian Studies, S.10, ss.283-320.

ROSENBERG, Matt (2019), "The Law of the Primate City, Primate Cities and the Rank-Size Rule", https://www.thoughtco.com/law-of-primate-cities-1435793 (Erişim Tarihi: 02.08.2021).

SAWERS, Larry (1989), "Urban Primacy in Tanzania", Economic Development and Cultural Change, S.37(4), ss.841-859.

SERHAU-SA/DPDM/MCOT (2006), Rapport économique de la ville de Cotonou. Cotonou, Bénin.

SHORT, John Rennie and PINET-PERALTA, Loius Mauricio (2009), "Urban Primacy: Reopening the Debate”, Geography Compass, S.3(3), ss.1245-1266.

SOTINDJA, Dossa Sébastien (1999), "Le doublet urbain Cotonou - Porto-Novo: les Raisons de Deux Capitales à Deux Vitesses”, Rev. CAMES, S.1, ss.90-100.

THOMLINSON, Ralph (1976), Population Dynamics: Causes and Consequences of World Demographic Change, Random House Publisher, New York (US).

TIMBERLAKE, Michael (2019), Primate Cities, University of Utah Publisher, Utah (US).

TOPALOV, Christian, COUDROY DE LILLE, Laurent, DEPAULLE, Jean-Charles and MARIN, Brigitte (2010), L'Aventure des Mots de la Ville, Robert Laffont, Paris.

WEBSTER, Noah (1973 [1828]), An American Dictionary of the English Language, Johnson Reprint Corp Publisher, New York (UK).

WHITNEY, William Dwight and SMITH, Benjamin Eli (1911), The Century Dictionary and Cyclopedia, The Century Company Publisher, New York (US). 